\title{
Prevalence and risk factors of diabetes in a large community-based study in the Sultanate of Oman: STEPS survey 2017
}

\author{
Adhra Al-Mawali ${ }^{1,2^{*}}$ D, Ayaman Al-Harrasi', Sathish Kumar Jayapal', Magdi Morsi ${ }^{1}$, Avinash Daniel Pinto',
} Waleed Al-Shekaili ${ }^{1}$, Hilal Al-Kharusi ${ }^{1}$, Zainab Al-Balushi ${ }^{1}$ and John Idikula ${ }^{1}$

\begin{abstract}
Background: Type 2 diabetes in the Gulf Cooperation Council countries, including Oman, is currently the fastest growing health crisis and is a significant cause of premature mortality and disability. There is currently insufficient up-to-date information available on prevalence of type 2 diabetes. This study aimed to assess the latest prevalence of type 2 diabetes mellitus and its associated demographic, behavioural, and clinical risk factors.

Methods: Using the WHO STEPwise approach to chronic disease surveillance, a nationally representative population-based survey was conducted from January to April 2017 of adults aged 18 years and above. A multistage, stratified, geographically clustered random sampling surveyed 9053 households including Omani nationals and non-Omani residents. Univariate and multiple logistic regression analysis was performed to determine the predictors of diabetes.

Results: Overall prevalence of diabetes among the population was $15.7 \%$ (95\% Cl: 14.0-17.5\%) whereas prevalence of prediabetes was $11.8 \%$ (95\% Cl: 11.4-12.2\%). Age, educational level, raised blood pressure, family history of diabetes, abnormal waist-to-hip ratio, and hypertriglyceridemia were found to be significantly associated with diabetes mellitus. Of the cases of diabetes mellitus, $17 \%$ were newly diagnosed and $13.2 \%$ were on medication and had an uncontrolled glucose level while 55.5\% were not taking medication (although diagnosed) and had an uncontrolled blood glucose level.

Conclusions: The present study provides reliable information regarding the high prevalence of diabetes mellitus among the adult population in Oman with urgent attention needed to address this significant burden on the health system. The high proportion of uncontrolled cases warrants further research, awareness programmes, and community interventions.
\end{abstract}

Keywords: Diabetes mellitus, Prevalence, Risk factors, Diabetes, Prediabetes, Oman, STEPS, NCD, Non-communicable disease, Control status

\footnotetext{
* Correspondence: adhra.almawali@moh.gov.om; adhra.almawali@gmail.com ${ }^{1}$ Centre of Studies \& Research, Ministry of Health, Muscat, Sultanate of Oman ${ }^{2}$ Strategic Research Program for Non-Communicable Diseases, Ministry of Higher Education, Research and Innovation, Muscat, Sultanate of Oman
}

C C The Author(s). 2021 Open Access This article is licensed under a Creative Commons Attribution 4.0 International License, which permits use, sharing, adaptation, distribution and reproduction in any medium or format, as long as you give appropriate credit to the original author(s) and the source, provide a link to the Creative Commons licence, and indicate if changes were made. The images or other third party material in this article are included in the article's Creative Commons. licence, unless indicated otherwise in a credit line to the material. If material is not included in the article's Creative Commons licence and your intended use is not permitted by statutory regulation or exceeds the permitted use, you will need to obtain permission directly from the copyright holder. To view a copy of this licence, visit http://creativecommons.org/licenses/by/4.0/ The Creative Commons Public Domain Dedication waiver (http://creativecommons.org/publicdomain/zero/1.0/) applies to the data made available in this article, unless otherwise stated in a credit line to the data. 


\section{Background}

Around 463 million people had diabetes mellitus (DM) in 2019 based on International Diabetes Federation estimates, with a projection of 700 million by 2040. From this, it is evident that DM is one of the fastest growing health crises facing the twenty-first century. Type 2 diabetes, the most common form, accounts for about $90 \%$ of all global diabetes cases. The global economic burden of DM is massive, with an estimated annual expenditure of USD 760 billion in 2019, projected to grow by $11.2 \%$ to USD 845 billion by 2045 [1].

Recent literature revealed that the prevalence of type 2 diabetes in the Gulf Cooperation Council (GCC) is high with a dramatic increase in the past two decades, and is expected to increase by $96.5 \%$ by 2045 [2,3]. Oman has been classified by the World Health Organization (WHO) as a country with low child and adult mortality rates (crude death rate: 2.4 per 1000). However, DM is currently the sixth leading cause of premature mortality in Oman and the fifth prominent cause of disabilityadjusted life years lost [4].

Diabetes prevalence estimation and identification of high-risk groups is vital for surveillance, and development of policies and community-based interventions. There is currently insufficient, up-to-date information available on prevalence of type 2 diabetes and its correlates in the Sultanate of Oman. Previous communitybased studies in Oman have been limited and do not truly represent all the risk factors and its relationships with diabetes in the Oman population [5-7]. This survey study, comprising the largest population-based survey in Oman so far, in collaboration with the WHO aimed to assess the latest prevalence of type $2 \mathrm{DM}$ and its associated demographic, behavioural, and clinical risk factors.

\section{Methods}

Sampling

Briefly, and as previously described in the STEPS survey 2017 main paper [8], a nation-wide non-communicable disease (NCD) risk factor survey based on WHO STEPwise approach to chronic disease surveillance was undertaken in all the governorates (regions) in the Sultanate of Oman from January 2017 to April 2017. The survey adopted a multi-stage stratified, geographically clustered random sampling approach using the 2010 national census sampling frame. Cluster sampling (based on the 2010 census blocks) was used and symmetric equal number of blocks were chosen in each governorate. A total of 9053 households, 823 households chosen from each governorate, were selected (Omani nationals and non-Omani national residents) with one adult being selected from each household randomly. Adjustment of sample weight was done for non-response at the household level. The target age group was 18 years or older.

\section{Data collection}

A culturally adapted, Arabic translated, and pre-tested version of the WHO STEPS questionnaire (version 3.1) was used $[8,9]$. As part of the household survey, sociodemographic and behavioural information on tobacco use, diet, physical activity, history of chronic diseases, family history of chronic conditions was collected in Step 1. Physical measurements such as height, weight, hip circumference, waist circumference, and blood pressure were collected in Step 2. Biochemical tests were conducted to measure fasting blood glucose, total cholesterol, and triglycerides in Step 3.

Data were collected by trained health professionals in the field. SECA adult portable stadiometers were used to measure height after removing shoes, socks, slippers and any head gear, with an accuracy up to $0.1 \mathrm{~cm}$. SECA ${ }^{\circ}$ digital weighing scales were used to measure the weight of the individuals. The scale was regularly calibrated against a standard weight. Waist circumference was measured using a $\mathrm{SECA}^{\circ}$ constant tension tape to the nearest $0.1 \mathrm{~cm}$. Blood pressure levels (both systolic blood pressure (SBP) and diastolic blood pressure (DBP)) were measured three times using the Omron M3 digital blood pressure device as recommended by $\mathrm{WHO}$, with the average of the closest two readings taken as the final reading. Overnight fasting blood samples were drawn to assess the biochemical profile of participants. For blood glucose and lipid profile measurements, dry chemistry method was used (CardioChek ${ }^{\bullet}$ Plus Analyzer). The reference biomarker cut-off points are mentioned under the heading of operational definitions.

\section{Data analysis}

Categorical variables are summarized using proportions and continuous variables using mean, with $95 \%$ confidence intervals. Chi square test was used for comparison of proportions across groups. Univariate and multiple logistic regression analysis was performed to determine the predictors of diabetes. All variables were entered into the multiple regression model to ensure that the interaction of all variables and their effects with the presence of other variables were measured. Statistical analysis was done using STATA/IC version 16.1.

\section{Ethical considerations}

The survey was approved by the Central Research and Ethical Review \& Approval Committee of the Ministry of Health, Sultanate of Oman. (Approval No: 26/2015). Written informed consent was obtained from participants for participation in the study separately during health history collection (STEP 1) and measurement of biophysiological parameters (STEP 2 \& 3). The confidentiality of the data gathered was maintained through a secure server. 


\section{Operational definitions}

Diagnostic criteria were based on WHO guidelines where diabetes was defined as individuals diagnosed by a physician and/or on antidiabetic medications and/or those who had fasting blood glucose $\geq 7 \mathrm{mmol} / \mathrm{l}$ ( $\geq 126$ $\mathrm{mg} / \mathrm{dl}$ ), while prediabetes or impaired fasting glucose was defined as fasting blood glucose $\geq 6.1 \mathrm{mmol} / \mathrm{l}$ ( $\geq 110$ $\mathrm{mg} / \mathrm{dl})$ and $<7 \mathrm{mmol} / \mathrm{l}(<126 \mathrm{mg} / \mathrm{dl})$. Current smoking included those individuals who were reported smoking in the month preceding the survey. Raised blood pressure was defined as individuals diagnosed by a physician and on antihypertensive medications (self-reported) and/ or those who had systolic blood pressure $\geq 140 \mathrm{mmHg}$ and/or diastolic blood pressure $\geq 90 \mathrm{mmHg}$ (WHO Criteria) $[10,11]$. One serving or portion of vegetables was considered to be $80 \mathrm{~g}$ or 1 cup of raw green leafy vegetables or $1 / 2$ cup of other cooked/chopped vegetables. One serving or portion of fruit was considered to be one whole medium-sized fruit or two smaller-sized fruits (WHO). Obesity was defined as Body Mass Index $(B M I) \geq 30$. Hypertriglyceridemia was defined as serum triglyceride levels $\geq 150 \mathrm{mg} / \mathrm{dl}$ ( $\geq 1.7 \mathrm{mmol} / \mathrm{l})$. Physical activity was assessed using the Global Physical Activity Questionnaire (GPAQ), which has been developed by the World Health Organization and used in the STEPS questionnaire [12, 13]. Participants were classified as sufficiently active when exceeding the minimum duration of physical activity per week recommended by WHO i.e. $150 \mathrm{~min}$ of moderate intensity physical activity or $75 \mathrm{~min}$ of vigorous intensity physical activity or an equivalent combination of moderate- and vigorous intensity physical activity [13]. Show cards (pictorial, adapted to the local context) were used to explain to the participants the type of physical activity, servings of fruits and vegetables and salty food intake [12].

\section{Results}

Table 1 shows the demographic characteristics of the respondents in the study. The overall response rate among survey participants was $75.5 \%$, with the figure for Omani nationals being $73.5 \%$. Majority of respondents were 30 39 years old (32.4\%), Omani nationals (70.6\%), had completed secondary school (34.3\%), and were not currently engaged in any form of employment (44.9\%).

\section{Prevalence of DM}

15.7\% (95\% CI: $14.0-17.5 \%$ ) of the survey participants were found to have DM (Table 2). The prevalence was similar among women (16.1\%) and men (15.4\%). A lower prevalence of raised blood glucose was seen in Omani nationals (14.5\%) as compared to non-Omani residents (18.8\%). Impaired glycaemia was prevalent among $11.8 \%$ of the population. Higher prevalence's were observed among women (12.6\%) and non-Omani residents
Table 1 Demographic characteristics of the participants

\begin{tabular}{|c|c|c|}
\hline Characteristics & $\mathbf{n}$ & Percentage \\
\hline \multicolumn{3}{|l|}{ Age groups (years) } \\
\hline $18-29$ & 1647 & 24.4 \\
\hline $30-39$ & 2187 & 32.4 \\
\hline $40-49$ & 1410 & 20.9 \\
\hline $50-59$ & 708 & 10.5 \\
\hline 60 and above & 630 & 9.3 \\
\hline \multicolumn{3}{|l|}{ Sex } \\
\hline Male & 3365 & 51.1 \\
\hline Female & 3217 & 48.9 \\
\hline \multicolumn{3}{|l|}{ Nationality } \\
\hline Omani & 4645 & 70.6 \\
\hline Non-Omani & 1937 & 29.4 \\
\hline \multicolumn{3}{|l|}{ Education Level } \\
\hline No formal education & 1772 & 26.9 \\
\hline Preparatory or lower & 988 & 15.0 \\
\hline Secondary completed & 2258 & 34.3 \\
\hline University and above & 1558 & 23.7 \\
\hline \multicolumn{3}{|l|}{ Employment status } \\
\hline Public sector employee & 1287 & 21.5 \\
\hline Private sector employee & 1766 & 29.5 \\
\hline Self-employed & 251 & 4.1 \\
\hline Not currently working & 2692 & 44.9 \\
\hline
\end{tabular}

(12.5\%) as compared to men $(11.1 \%$, ) and Omani (11.5\%), respectively.

\section{Risk factors for DM}

All demographic, lifestyle, and clinical variables were entered in a multivariate regression analysis model. In terms of demographic covariates, age group $(p<.001)$ and educational level $(p<.05)$ were found to be the risk factors significantly associated with DM (Table 3). In terms of lifestyle and clinical covariates, raised blood pressure $(p<.05)$, family history of diabetes $(p<.001)$, abnormal waist-to-hip ratio $(p<.001)$, and hypertriglyceridemia $(p<.001)$ were found to be significantly associated with DM (Table 4).

\section{Treatment and control status of DM}

Among all the respondents with raised blood glucose or on medication for blood glucose, $83 \%$ were known cases of DM while $17 \%$ were newly diagnosed (Table 5). $14.3 \%$ of respondents were on a specific anti-diabetic medication and had a controlled glucose level (treatment success), $13.2 \%$ were on medication and a raised blood glucose level (treatment failure), and 55.5\% were not taking medication (although diagnosed) and had a raised blood glucose level. 
Table 2 Prevalence of diabetes mellitus (DM) and pre-diabetes by nationality and demographic characteristics

\begin{tabular}{|c|c|c|c|c|c|c|}
\hline \multirow[t]{2}{*}{ Characteristics } & \multicolumn{2}{|l|}{ Omani } & \multicolumn{2}{|l|}{ Non-Omani } & \multicolumn{2}{|l|}{ Total } \\
\hline & $\begin{array}{l}\text { Prevalence of pre- } \\
\text { diabetes N } \%, 95 \\
\mathrm{Cl})\end{array}$ & $\begin{array}{l}\text { Prevalence of } \\
\text { diabetes N } \% \text {, } \\
95 \mathrm{Cl})\end{array}$ & $\begin{array}{l}\text { Prevalence of pre- } \\
\text { diabetes } \mathrm{N}(\%, 95 \\
\mathrm{Cl})\end{array}$ & $\begin{array}{l}\text { Prevalence of } \\
\text { diabetes N }(\% \text {, } \\
95 \mathrm{Cl})\end{array}$ & $\begin{array}{l}\text { Prevalence of pre- } \\
\text { diabetes } \mathrm{N}(\%, 95 \\
\mathrm{Cl})\end{array}$ & $\begin{array}{l}\text { Prevalence of } \\
\text { diabetes N } \% \text {, } \\
95 \mathrm{Cl})\end{array}$ \\
\hline \multicolumn{7}{|l|}{ Age group } \\
\hline $18-29$ & $138(8.6,(7.7-9.6))$ & $55(3.1,(2.1-4.4))$ & $80(11.8,(9.8-14.1))$ & $34(3.2,(1.9-5.2))$ & $218(9.3,(8.4-10.2))$ & $89(3.1,(2.3-4.2))$ \\
\hline $30-39$ & $201(12.8,(11.8-13.9))$ & $119(6.1,(4.7-7.8))$ & $112(13,(11.3-14.9))$ & $99(12.4,(9.2-16.5))$ & $313(12.9,(12.1-13.7))$ & $\begin{array}{l}218(8.23,(6.7- \\
10.0))\end{array}$ \\
\hline $40-49$ & $148(14.6,(12.9-16.6))$ & $\begin{array}{l}166(20.6,(14.7- \\
28.1))\end{array}$ & $83(11.3,(9.7-13))$ & $\begin{array}{l}105(25.7,(20.0- \\
32.2))\end{array}$ & $231(13.5,(12.2-14.9))$ & $\begin{array}{l}271(22.3,(17.9- \\
27.5))\end{array}$ \\
\hline $50-59$ & $81(10.5,(9.1-12))$ & $\begin{array}{l}162(34.7,(26.6- \\
3.7))\end{array}$ & $30(15.3,(12.7-18.3))$ & $\begin{array}{l}81(37.8,(27.5- \\
49.3))\end{array}$ & $111(11.7,(10.4-13))$ & $\begin{array}{l}243(35.5,(28.8- \\
42.8))\end{array}$ \\
\hline 60 \& above & $91(12.6,(11.5-13.9))$ & $\begin{array}{l}205(39.8,(31.7- \\
48.4))\end{array}$ & $5(11.2,(7.4-16.5))$ & $\begin{array}{l}28(58.0,(38.5- \\
75.2))\end{array}$ & $96(12.4,(11.3-13.6))$ & $\begin{array}{l}233(42.6,(35.1- \\
50.5))\end{array}$ \\
\hline \multicolumn{7}{|l|}{ Sex } \\
\hline Male & $249(10.1,(9.4-10.8))$ & $\begin{array}{l}253(13.5,(10.3- \\
17.4))\end{array}$ & $261(12.4,(11.1-13.9))$ & $\begin{array}{l}290(18.4,(15.3- \\
22.0))\end{array}$ & $510(11,(10.3-11.7))$ & $\begin{array}{l}543(15.4,(13.0- \\
18.1))\end{array}$ \\
\hline Female & $410(12.6,(11.8-13.4))$ & $\begin{array}{l}454(15.3,(13.0- \\
18.1))\end{array}$ & $49(12.3,(10.1-14.9))$ & $\begin{array}{l}57(20.1,(14.3- \\
27.5))\end{array}$ & $459(12.6,(11.8-13.3))$ & $\begin{array}{l}511(16.1,(13.8- \\
18.6))\end{array}$ \\
\hline \multicolumn{7}{|l|}{ Education level } \\
\hline $\begin{array}{l}\text { No formal } \\
\text { education }\end{array}$ & $230(15.5,(14.4-16.8))$ & $\begin{array}{l}373(31.8,(27.0- \\
37.0))\end{array}$ & $76(14.7,(13.3-16.3))$ & $\begin{array}{l}83(23.6,(17.5- \\
30.9))\end{array}$ & $306(15.4,(14.4-16.4))$ & $\begin{array}{l}456(30.3,(26.2- \\
34.8))\end{array}$ \\
\hline $\begin{array}{l}\text { Preparatory or } \\
\text { less }\end{array}$ & $80(12.6,(10.9-14.4))$ & $\begin{array}{l}98(23.4,(17.6- \\
30.3))\end{array}$ & $75(13.5,(12.2-14.9))$ & $\begin{array}{l}88(20.4,(15.4- \\
26.5))\end{array}$ & $155(12.9,(11.8-14.1))$ & $\begin{array}{l}186(22.2,(18.1- \\
27.0))\end{array}$ \\
\hline $\begin{array}{l}\text { Secondary } \\
\text { completed }\end{array}$ & $224(10.3,(9.6-11.1))$ & $156(8.5,(5.7-12.2))$ & $74(10.5,(8.6-12.7))$ & $\begin{array}{l}96(22.3,(15.5- \\
31.0))\end{array}$ & $298(10.4,(9.7-11.1))$ & $\begin{array}{l}252(11.0,(8.4- \\
14.2))\end{array}$ \\
\hline $\begin{array}{l}\text { University \& } \\
\text { above }\end{array}$ & $124(9.7,(8.6-11))$ & $80(7.57,(4.7-11.9))$ & $85(12.5,(10.6-14.6))$ & $\begin{array}{l}79(15.0,(11.1- \\
19.9))\end{array}$ & $209(10.8,(9.8-11.9))$ & $\begin{array}{l}159(10.5,(8.0- \\
13.6))\end{array}$ \\
\hline \multicolumn{7}{|l|}{ Marital Status } \\
\hline Never married & $89(8.3,(7.4-9.4))$ & $42(4.3,(2.1-8.5))$ & $72(12.1,(9.6-15.1))$ & $33(5.3,(2.8-9.8))$ & $161(9.1,(8.2-10.2))$ & $75(4.6,(2.6-7.7))$ \\
\hline $\begin{array}{l}\text { Currently } \\
\text { married }\end{array}$ & $496(13,(12.3-13.7))$ & $\begin{array}{l}544(17.3,(14.7- \\
20.1))\end{array}$ & $233(12.6,(11.3-13.9))$ & $\begin{array}{l}309(22.2,(18.9- \\
25.8))\end{array}$ & $729(12.8,(12.3-13.4))$ & $\begin{array}{l}853(18.8,(16.7- \\
21.0))\end{array}$ \\
\hline $\begin{array}{l}\text { Divorced/ } \\
\text { Separated }\end{array}$ & $22(12.3,(9.8-15.2))$ & $91(22.2,(8.8-45.5))$ & $4(16.2,(9.3-26.7))$ & $2(48.3,(12.5-85.9))$ & $26(12.5,(10.1-15.3))$ & $\begin{array}{l}103(23.6,(10.4- \\
5.3))\end{array}$ \\
\hline Widowed & $52(10.6,(9.1-12.3))$ & $\begin{array}{l}98(34.7,(24.0- \\
47.1))\end{array}$ & $1(3.3,(1.7-6.2))$ & $3(30.5,(5.4-76.9))$ & $53(10.1,(8.7-11.7))$ & $\begin{array}{l}101(34.4,(24.1- \\
6.4))\end{array}$ \\
\hline \multicolumn{7}{|l|}{ Work status } \\
\hline $\begin{array}{l}\text { Public sector } \\
\text { employee }\end{array}$ & $163(13.7,(12.3-15.1))$ & $\begin{array}{l}124(11.4,(8.2- \\
15.7))\end{array}$ & $32(11.2,(8.7-14.2))$ & $27(13.6,(7.8-22.6))$ & $195(13.4,(12.2-14.7))$ & $\begin{array}{l}151(11.6,(8.6- \\
15.5))\end{array}$ \\
\hline $\begin{array}{l}\text { Private sector } \\
\text { employee }\end{array}$ & $60(5.9,(5.2-6.7))$ & $77(13.9,(7.5-24.4))$ & $244(12.5,(11.3-13.9))$ & $\begin{array}{l}278(17.8,(14.7- \\
21.3))\end{array}$ & $304(10.3,(9.4-11.3))$ & $\begin{array}{l}355(16.5,(13.3- \\
20.3))\end{array}$ \\
\hline $\begin{array}{l}\text { Not currently } \\
\text { working }\end{array}$ & $435(11.9,(11.3-12.6))$ & $\begin{array}{l}506(15.9,(13.5- \\
18.5))\end{array}$ & $34(12.4,(10.2-14.9))$ & $\begin{array}{l}42(24.6,(17.0- \\
34.2))\end{array}$ & $469(11.9,(11.3-12.6))$ & $\begin{array}{l}548(16.8,(14.5- \\
19.4))\end{array}$ \\
\hline Total & $659(11.5,(11.0-12.1))$ & $\begin{array}{l}707(14.5,(12.5- \\
16.8))\end{array}$ & $310(12.5,(11.7-13.3))$ & $\begin{array}{l}347(18.8,(16.0- \\
22.0))\end{array}$ & $969(11.8,(11.4-12.2))$ & $\begin{array}{l}1054(15.7,(14.0- \\
17.5))\end{array}$ \\
\hline
\end{tabular}

Small but significantly higher prevalence was observed for Omani nationals under medication and had controlled blood glucose status compared to non-Omani residents $(15.3 \%$ vs $12.3 \%, p<0.05)$, but no significant difference was found between male and females in this group. A majority of newly discovered cases with raised blood glucose level was observed in the 18-29 years age group (39.2\%), males (20.8\%) and non-Omani residents (24.5). Similarly, a majority of respondents not currently on medication and raised blood glucose level was found among 40-49years old (61\%), and Omani nationals (56.5\%).

Figure 1 reveals that among the $14.5 \%$ Omani nationals, $86.6 \%$ were picked by the health system and 


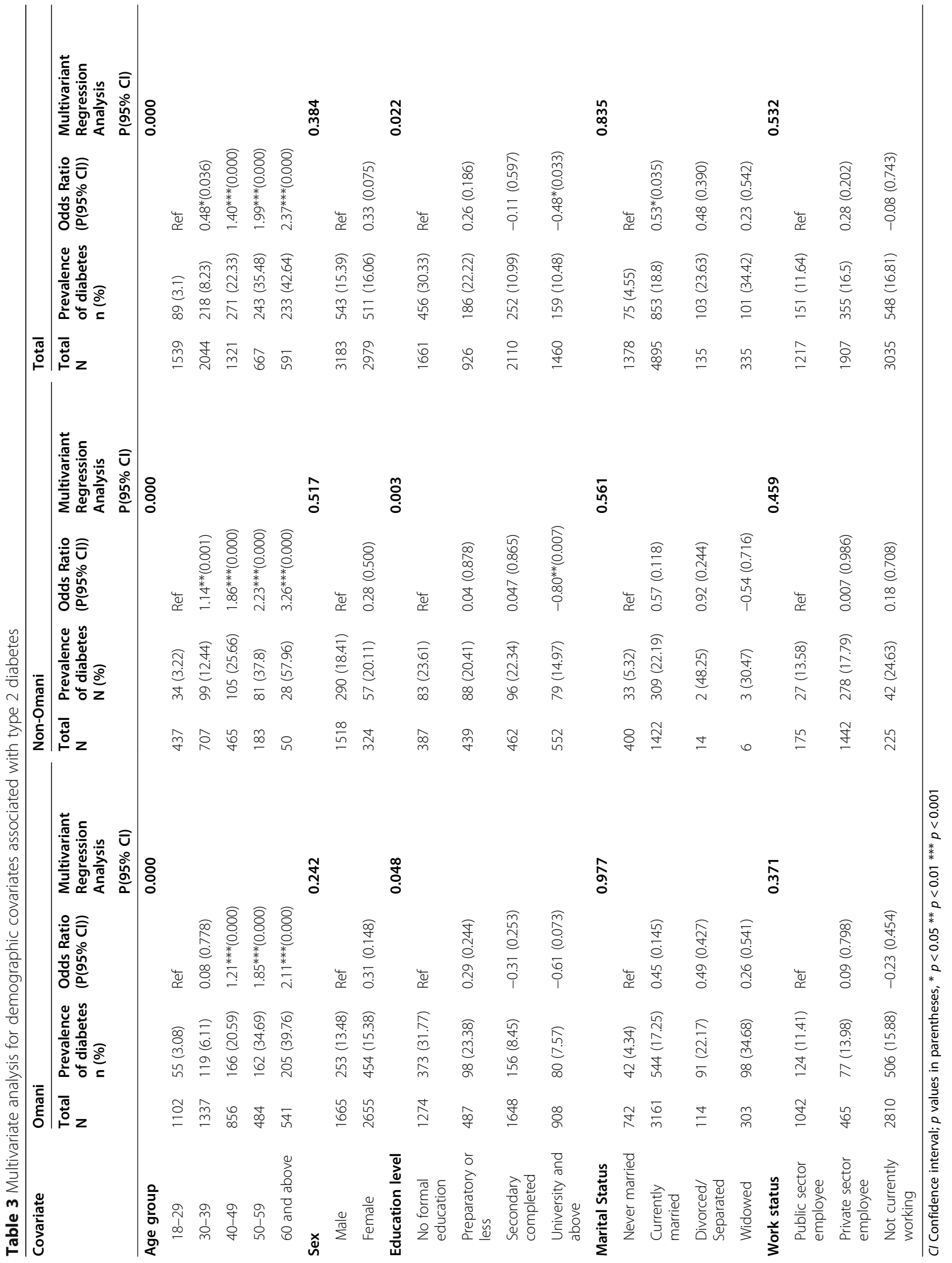




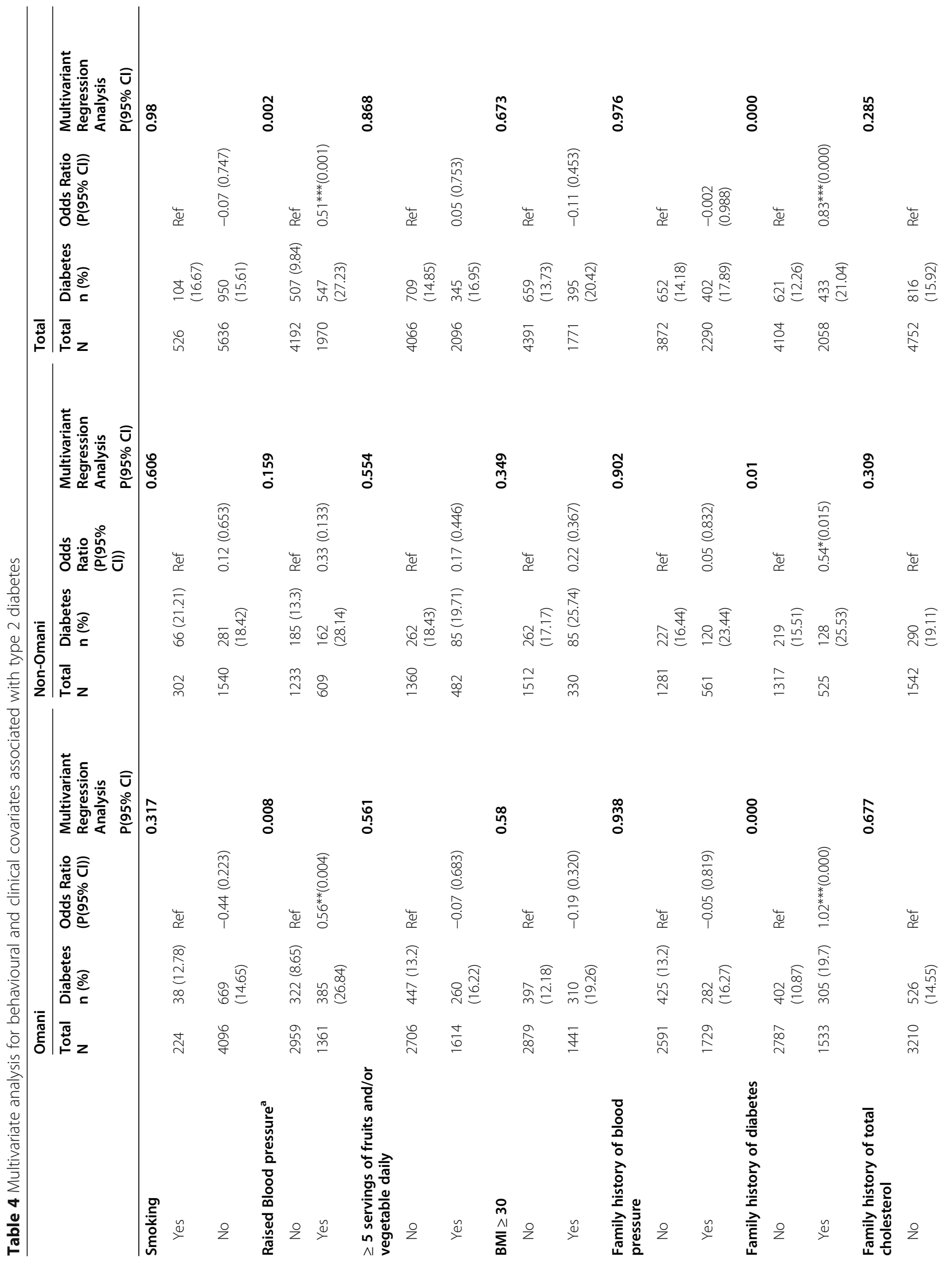




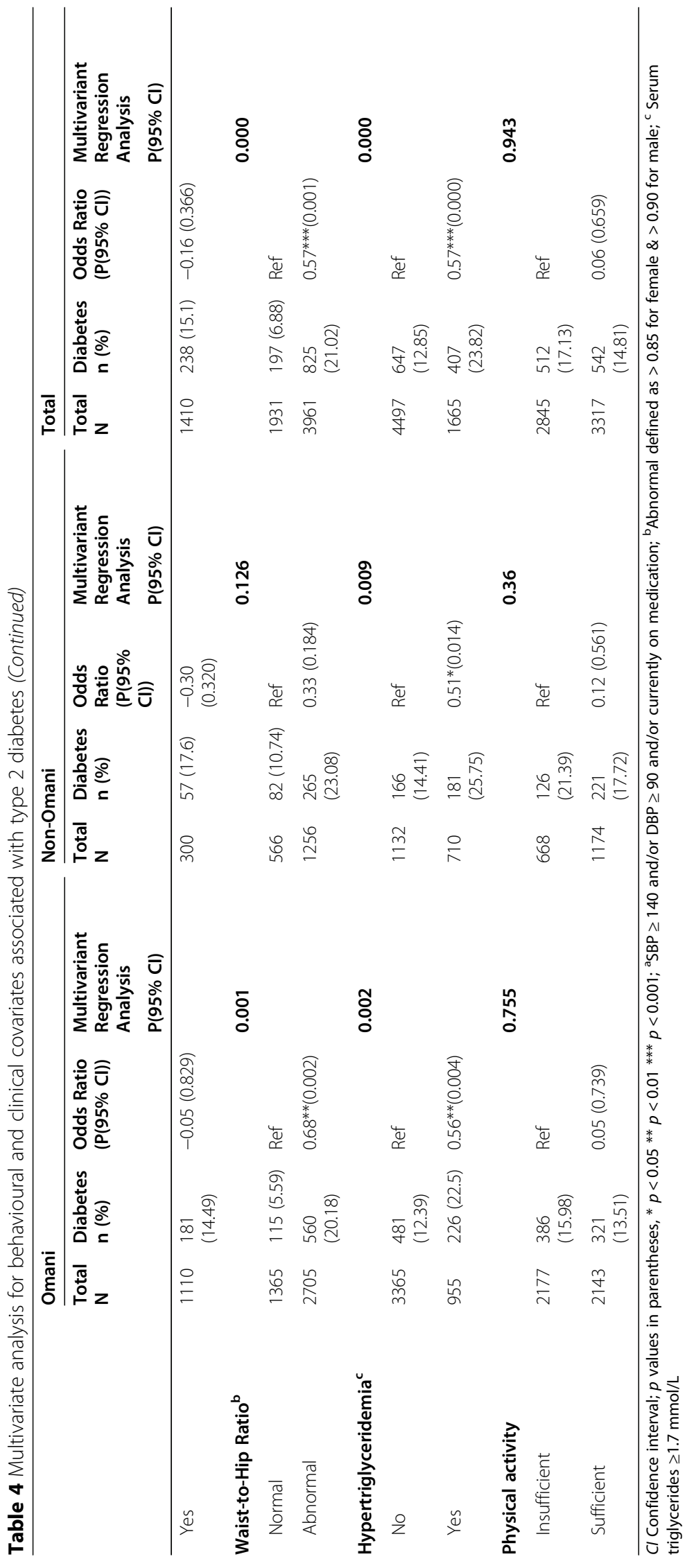


Table 5 Prevalence of the population with raised blood glucose or on medication for blood glucose disaggregated by diagnosis and treatment status

\begin{tabular}{|c|c|c|c|c|c|}
\hline Category & $\begin{array}{l}\text { On medication and } \\
\text { glucose }<7 \mathrm{mmol} / \mathrm{L}\end{array}$ & $\begin{array}{l}\text { On medication and } \\
\text { glucose } \geq 7 \mathrm{mmol} / \mathrm{L}\end{array}$ & $\begin{array}{l}\text { Not aware of raised } \\
\text { glucose } \geq 7 \mathrm{mmol} / \mathrm{L}\end{array}$ & $\begin{array}{l}\text { Not taking prescribed medication and } \\
\text { glucose } \geq 7 \mathrm{mmol} / \mathrm{L}\end{array}$ & $\begin{array}{l}\text { Total } \\
\mathrm{N}\end{array}$ \\
\hline \multicolumn{6}{|l|}{ Age group } \\
\hline $18-29$ & $12.0(0.7-2.3)$ & $10.3(6.9-15.1)$ & $39.2(34.3-44.3)$ & $49.2(43.9-54.6)$ & 87 \\
\hline $30-39$ & $6.6(4.9-8.9)$ & $6.5(4.9-8.5)$ & $29.1(25.9-32.3)$ & $57.8(54.2-61.4)$ & 215 \\
\hline $40-49$ & $12.1(10.3-14.2)$ & $10.1(8.3-12.1)$ & $16.7(14.4-19.2)$ & $61.1(57.0-65.0)$ & 259 \\
\hline $50-59$ & $25.3(21.8-29.1)$ & $11.3(9.5-13.4)$ & $8.8(7.5-10.3)$ & $54.6(50.4-58.8)$ & 236 \\
\hline $60+$ & $14.2(12.0-16.5)$ & $23.3(19.9-27.1)$ & $12.8(10.8-15.0)$ & $49.8(45.2-54.4)$ & 226 \\
\hline \multicolumn{6}{|l|}{ Sex } \\
\hline Male & $13.0(11.5-14.8)$ & $10.4(8.9-12.2)$ & $20.8(19-22.7)$ & $55.7(52.6-58.7)$ & 526 \\
\hline Female & $15.7(13.9-17.6)$ & $16.0(14.2-18)$ & $13.0(11.5-14.6)$ & $55.3(25.5-58.1)$ & 497 \\
\hline \multicolumn{6}{|c|}{ Nationality } \\
\hline Omani & $15.3(13.8-17.0)$ & $14.9(13.3-16.6)$ & $13.4(12.1-14.7)$ & $56.5(53.7-59.1)$ & 683 \\
\hline $\begin{array}{l}\text { Non- } \\
\text { Omani }\end{array}$ & $12.3(10.4-14.5)$ & $9.7(7.9-11.7)$ & $24.5(22.2-26.8)$ & $53.6(50.6-56.6)$ & 340 \\
\hline Overall & $14.3(13.1-15.6)$ & $13.2(12-14.5)$ & $\mathbf{1 7 . 0}(15.9-18.2)$ & $\mathbf{5 5 . 5}(53.4-57.6)$ & 1023 \\
\hline
\end{tabular}

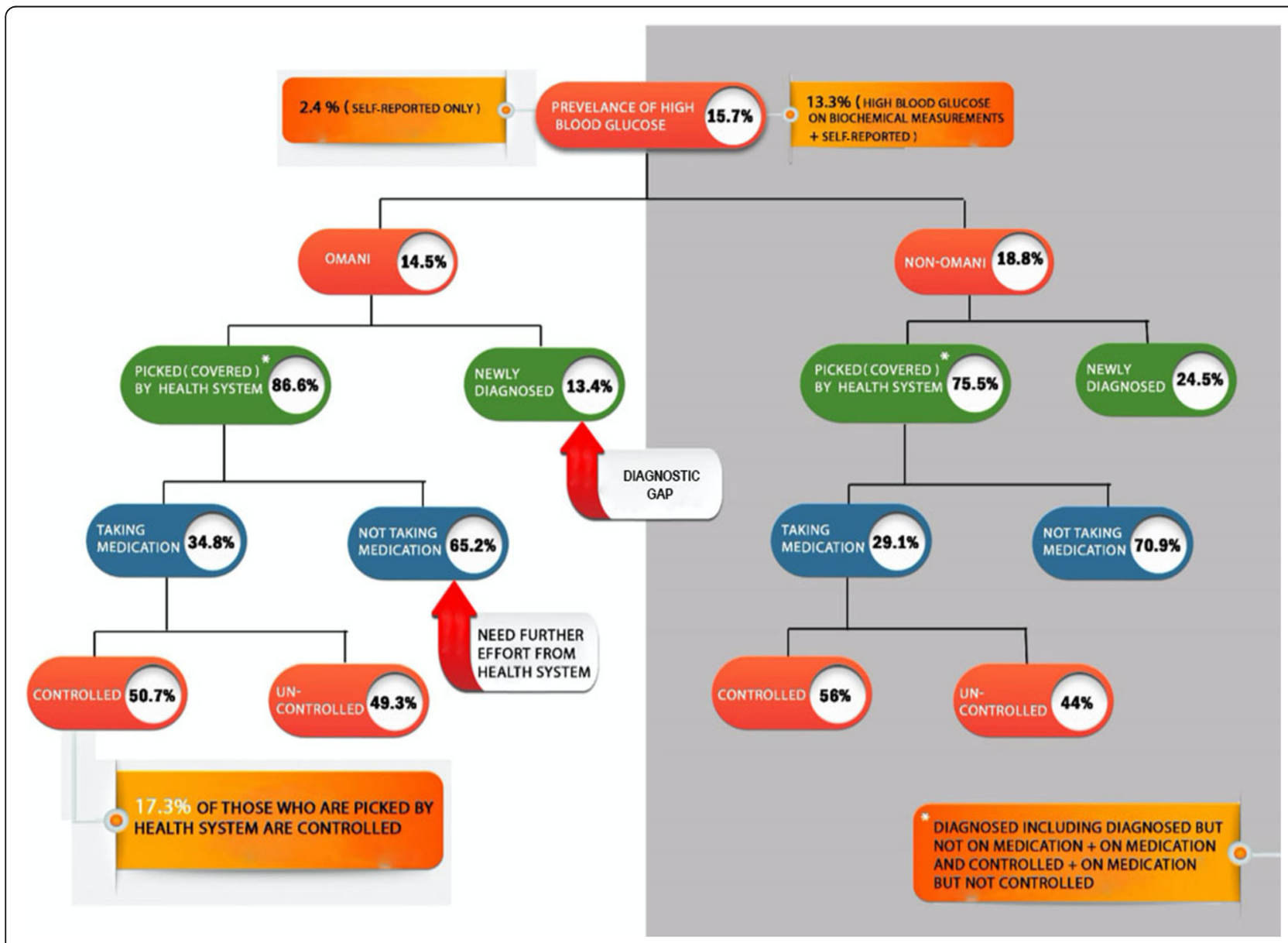

Fig. 1 Diabetes chart by nationality, diagnosis, treatment status, and control status 
$13.4 \%$ were newly diagnosed. Of those who were covered by the health system, only $34.8 \%$ were taking the prescribed medications and $65.2 \%$ were not. Of those who were taking their prescribed medication, only 50.7\% were controlled for DM. This demonstrates that only $17.3 \%$ of those who were picked by the health system had controlled blood glucose status. Similarly, for the $18.8 \%$ of non-Omani residents, $75.5 \%$ were picked by the health system and $24.5 \%$ were newly diagnosed. Of those who were covered by the health system, only $29 \%$ were taking the medications. Of those who were taking medication, only $56 \%$ were controlled for DM.

\section{Discussion}

This study represents the largest multistage stratified community-based national survey in Oman which included all the 11 governorates of Oman. A high response rate was achieved with the employment of the standardized STEPS questionnaire, robust methodology, and adherence to STROBE guidelines [14].

The results of this survey revealed a high prevalence of DM and prediabetes among the Oman population. Some national and regional surveys were conducted previously which showed the prevalence of diabetes between 1991 and 2010, with the last main national survey conducted in 2008 [5]. An increase in the prevalence of DM was found from the 2008 national survey (12.3\%) when compared to our results in 2017 (15.7\%) [15]. Strikingly, there has been a sharp increase in prevalence of prediabetes from $4.4 \%$ in 2008 to $11.8 \%$ in the current study. Our results for DM were similar to other STEPS studies conducted in the WHO Eastern Mediterranean (EMR) region, but higher than the prevalence reported in other Asian countries [16-19]. Omani nationals (14.5\%) were found to have a significantly lower prevalence than nonOmani residents (18.8\%) in this survey. This may be attributed to the universal healthcare system which provides free primary healthcare for Omani citizens and the difference in lifestyle between the two subgroups.

It has been reported that biological composition as well as obesity has an effect on sex differences associated with the burden and complication of DM [20]. In this present study, the prevalence of diabetes and prediabetes is slighter higher (though not significant) in females than in males as opposed to other studies globally which show a higher prevalence among males as compared to females $[19,21,22]$. Our results are corroborated by higher prevalence of overweight and obesity found among females than males in the survey [8]. Our results show that one third of the population with DM are under the age of 50. Based on these results, DM did increase with age although it is not limited to older subjects. This adds to the growing body of evidence suggesting that diabetes is also evolving among the younger population as well $[18,19,23]$.

Different studies showed that both or either overall obesity or central obesity was associated with conferring risk of diabetes $[18,19]$. This study found that an abnormal waist-hip ratio was independently associated with diabetes which is similar to the results in most of the other studies [24-26]. Literature has already shown the protective effects of physical activity against obesity [27]. It is well known that family history of DM is a strong, independent predictor of the disease which was confirmed in our study and supported by most other studies which can be used as a public health tool $[28,29]$. Hypertriglyceridemia, but not family history of total cholesterol, was significantly associated with diabetes. Constant increments in serum triglyceride levels were found to be an independent risk factor for diabetes mellitus as well as associated with increased risk for CVD $[30,31]$. The study results indicate that elderly individuals, hypertensive, or those with a family history of DM comprise an notable group for screening [5, 24, 27].

The ratio of newly diagnosed to total patients with DM (17\%) was found to be considerably lower as compared to the 2008 national survey [15]. This proportion comes down to $13 \%$ for Omanis and could be attributed to the national non-communicable diseases screening program for those aged 40 years and above. The DM cases with controlled glucose level have also shown a slight reduction from 2008 ( $17 \%$ in 2008 vs $14 \%$ in 2017). However, most concerning is the bulk of uncontrolled cases which accounts for over two-thirds of the cases with raised blood glucose, out of which around $56 \%$ are not taking any medication to control their blood glucose level although they have been diagnosed with DM. It is this pool of cases of DM left uncontrolled which would become more prone to complications, and ultimately put a higher financial strain on the country. When assessing only the Omani national population who are served by free primary healthcare, about half of those taking medication were shown to have a controlled blood glucose status. This reveals that only $17 \%$ of the individuals who were picked by the health system had a controlled blood glucose status, which is an alarming figure. Challenges of health promotion as part of Oman's Health Vision 2050 have to be tackled to address unsafe behaviours and subsequently health-related interventions [32]. It is of paramount importance that further research looks into understanding the underlying issues to be able to address them at the root level [33].

\section{Study limitations}

Firstly, due to the nature of the study design being crosssectional, any casual inferences should be interpreted with caution. Secondly, blood glucose measurement was done 
by a spot analyser rather than venous blood glucose estimation due to logistical constraints. However, regular quality control checks on blood glucose measurement was done as per the manufacturer's instructions. Thirdly, only fasting blood glucose level was used to measure for diabetes and prediabetes rather than the more sensitive oral glucose tolerance test (OGTT) or the HbA1c test due to financial and logistical constraints of a large-scale household community survey.

\section{Conclusion}

In conclusion, the current study provides reliable evidence regarding the high burden of DM among the adult population in Oman. With around 28\% of the general population having either diabetes or prediabetes, urgent attention is needed to address this significant burden on the health system. The newly diagnosed cases of DM in the community should not be neglected and also be offered early treatment in order to avoid complications. The reasons for uncontrolled DM in Oman warrant further research and innovative strategies to address this population. Prevention of DM should have a high priority in public health development plans in Oman to prevent associated rising economic costs.

\section{Abbreviations}

DM: Diabetes mellitus; USD: United States Dollars; GCC: Gulf Cooperation Council; WHO: World Health Organization; MENA: Middle Eastern and North African; BMI: Body Mass Index; GPAQ: Global Physical Activity Questionnaire; STROBE: Strengthening the Reporting of Observational Studies in Epidemiology; EMR: Eastern Mediterranean Region; NCD: Non-communicable Diseases

\section{Acknowledgements}

The authors acknowledge the support provided by the Director General of Planning and Studies, Ministry of Health, Oman, the WHO country office \& WHO EMRO office for their contributions, and the data collectors for the execution of the survey.

\section{Authors' contributions}

AAM, AAH, MM, WAS, ADP, HAK, AAH, ZAB, Jl contributed substantially to the acquisition. AAH \& MM performed the data analysis. AAM, AAH, SK, ADP contributed to interpretation of data, drafted the work and substantively revised it. All authors have read and approved the final manuscript.

\section{Funding}

Special thanks to our funding agencies Omantel, Petroleum Development Oman (PDO), OQ, and SSW Group of companies who supported this national level survey. The funding bodies had no role in the design of the study and collection, analysis, interpretation of data, and writing the manuscript.

\section{Availability of data and materials}

The datasets generated and/or analysed during the current study are not publicly available due to data sharing policies but are available from the corresponding author on reasonable request.

\section{Ethics approval and consent to participate}

The study protocol was approved by the Central Research and Ethical Review \& Approval Committee of the Ministry of Health, Sultanate of Oman (Approval No: 26/2015). Written informed consent was obtained from the participants for participation in this study separately during health history collection and measurement of bio-physiologic parameters.
Consent for publication

Not applicable.

\section{Competing interests}

The authors declare that they have no competing interests.

Received: 25 August 2020 Accepted: 17 November 2020

Published online: 05 March 2021

\section{References}

1. International Diabetes Federation. IDF Diabetes Atlas. 2019. Report No.: Ninth Edition 2019. Available from: diabetesatlas.org/en/resources.

2. Al Slamah T, Nicholl BI, Alslail FY, Melville CA. Self-management of type 2 diabetes in gulf cooperation council countries: a systematic review. PLoS One. 2017:12(12):e0189160.

3. Morgan SA, Ali MM, Channon AA, Al-Sabahi S, Al Suwaidi H, Osman N, et al. Prevalence and correlates of diabetes and its comorbidities in four gulf cooperation council countries: evidence from the world health survey plus. J Epidemiol Community Health. 2019;73(7):630-6.

4. Institute for Health Metrics and Evaluation. Oman. Global Burden of Disease Study 2017 (GBD 2017). 2018 [cited 2020 Jul 2]. Available from: healthdata. org/oman.

5. Al-Lawati JA, Panduranga P, Al-Shaikh HA, Morsi M, Mohsin N, Khandekar $\mathrm{RB}$, et al. Epidemiology of diabetes mellitus in Oman results from two decades of research. Sultan Qaboos Univ Med J. 2015;15(2):e226-33.

6. Asfour MG, Samantray SK, Dua A, King H. Diabetes mellitus in the Sultanate of Oman. Diabet Med. 1991;8(1):76-80.

7. Majeed A, El-Sayed AA, Khoja T, Alshamsan R, Millett C, Rawaf S. Diabetes in the middle-east and North Africa: an update. Diabetes Res Clin Pract. 2014; 103(2):218-22.

8. Al-Mawali A, Jayapal SK, Morsi M, Al-Shekaili W, Pinto AD, Al-Kharusi H, et al. Prevalence of Risk Factors of Non-Communicable Diseases in the Sultanate of Oman: STEPS Survey 2017; 2020. https://doi.org/10.21203/rs.2.20937/v1.

9. NCDs / The STEPS Instrument and Support Materials. [cited 2020 May 12]. Available from: https://www.who.int/ncds/surveillance/steps/instrument/en/.

10. Hypertension. [cited 2020 May 12]. Available from: https://www.who.int/ health-topics/hypertension/\#tab=tab_1.

11. $\mathrm{WHO} \mid$ The guideline development group for the diagnosis and pharmacological treatment of hypertension in adults. WHO. 2020. Available from: https://www.who.int/cardiovascular_diseases/guidelines/hypertension/ en/

12. Global Physical activity Questionaire Analysis. World Health Organisations. [cited 2020 May 12]. Available from: https://www.who.int/ncds/surveillance/ steps/resources/GPAQ_Analysis_Guide.pdf.

13. Global Physical Activity Questionnaire Analysis Guide GPAQ Analysis Guide Global Physical Activity Questionnaire (GPAQ) Analysis Guide.[cited 2020 May 12] Available from: https://www.who.int/ncds/surveillance/steps/ resources/GPAQ_Analysis_Guide.pdf.

14. STROBE Statement. STROBE group. 2014 [cited 2020 May 12]. Available from: https://www.strobe-statement.org/index.php?id=strobe-home

15. Morsi M, Elaty A, Attia M, Al RA. Oman world health survey: part 1 methodology, sociodemographic profile and epidemiology of noncommunicable diseases in Oman. Oman Med J. 2012;100(330):1-19.

16. Tripathy JP, Thakur JS, Jeet G, Chawla S, Jain S, Pal A, et al. Prevalence and risk factors of diabetes in a large community-based study in North India: results from a STEPS survey in Punjab, India. Diabetol Metab Syndr. 2017; $9(1): 1-8$.

17. World Health Organization. Noncommunicable diseases and their risk factors. STEPS Country Reports. [cited 2020 Jul 1]. Available from: who.int/ ncds/surveillance/steps/reports/en.

18. Akter S, Rahman MM, Abe SK, Sultana P. Prevalence of diabetes and prediabetes and their risk factors among Bangladeshi adults: a nationwide survey. Bull World Health Organ. 2014;92:204-213A.

19. Pham NM, Eggleston K. Prevalence and determinants of diabetes and prediabetes among Vietnamese adults. Diabetes Res Clin Pract. 2016;113: $116-24$

20. Peters SA, Woodward M. Sex differences in the burden and complications of diabetes. Curr Diab Rep. 2018;18(6):33.

21. Msyamboza KP, Mvula CJ, Kathyola D. Prevalence and correlates of diabetes mellitus in Malawi: population-based national NCD STEPS survey. BMC Endocr Disord. 2014;14(1):41. 
22. Gaio V, Antunes L, Namorado S, Barreto M, Gil A, Kyslaya I, et al. Prevalence of overweight and obesity in Portugal: results from the first Portuguese health examination survey (INSEF 2015). Obes Res Clin Pract. 2018;12(1):40-50.

23. Hilawe EH, Chiang C, Yatsuya H, Wang C, Ikerdeu E, Honjo K, et al. Prevalence and predictors of prediabetes and diabetes among adults in Palau: population-based national STEPS survey. Nagoya J Med Sci. 2016; 78(4):475.

24. Al-Lawati JA, Jousilahti PJ. Prevalence and 10-year secular trend of obesity in Oman. Saudi Med J. 2004;25(3):346-51.

25. Al-Riyami AA, Afifi MM. Prevalence and correlates of obesity and central obesity among Omani adults. Saudi Med J. 2003 Jun;24(6):641-6.

26. Balhareth A, Meertens R, Kremers S, Sleddens E. Overweight and obesity among adults in the Gulf States: A systematic literature review of correlates of weight, weight-related behaviours, and interventions. Obesity Rev. Blackwell Publishing Ltd. 2019:20:763-93.

27. Mabry R, Owen N, Eakin E. A National Strategy for promoting physical activity in Oman: a call for action. Sultan Qaboos Univ Med J. 2014;14(2):e170-5.

28. Hariri S, Yoon PW, Qureshi N, Valdez R, Scheuner MT, Khoury MJ. Family history of type 2 diabetes: a population-based screening tool for prevention? Genet Med. 2006;8(2):102-8.

29. Consortium I. Others. The link between family history and risk of type 2 diabetes is not explained by anthropometric, lifestyle or genetic risk factors: the EPIC-InterAct study. Diabetologia. 2013;56(1):60-9.

30. Ye X, Kong W, Zafar MI, Chen L-L. Serum triglycerides as a risk factor for cardiovascular diseases in type 2 diabetes mellitus: a systematic review and meta-analysis of prospective studies. Cardiovasc Diabetol. 2019:18(1):1-10.

31. Beshara A, Cohen E, Goldberg E, Lilos P, Garty M, Krause I. Triglyceride levels and risk of type 2 diabetes mellitus: a longitudinal large study. J Investig Med. 2016;64(2):383-7.

32. Al Hinai H, Al Mufarji K, Al Siyabi H, Al Anqoudi Z, Al Saadi R, Al Awaidy S. Health promotion strategy as part of Vision 2050 in Oman: the way forward. Global Health Promotion. 2020;27(4):145-9. https://doi.org/10.1177/ 1757975920909115.

33. Al Mawali AHN, Al Qasmi AM, Al Sabahi SMS, Idikula J, Abd Elaty MA, Morsi $\mathrm{M}$, et al. Oman vision 2050 for health research: a strategic plan for the future based on the past and present experience. Oman Med J. 2017;32(2): 86.

\section{Publisher's Note}

Springer Nature remains neutral with regard to jurisdictional claims in published maps and institutional affiliations.

Ready to submit your research? Choose BMC and benefit from:

- fast, convenient online submission

- thorough peer review by experienced researchers in your field

- rapid publication on acceptance

- support for research data, including large and complex data types

- gold Open Access which fosters wider collaboration and increased citations

- maximum visibility for your research: over $100 \mathrm{M}$ website views per year

At $\mathrm{BMC}$, research is always in progress.

Learn more biomedcentral.com/submissions 